\title{
Acid-functionalized amphiphiles, derived from polystyrene-poly (propylene imine) dendrimers, with a pH-dependent aggregation
}

Citation for published version (APA):

Hest, van, J. C. M., Baars, M. W. P. L., Roman Vas, C., Genderen, van, M. H. P., \& Meijer, E. W. (1995). Acidfunctionalized amphiphiles, derived from polystyrene-poly (propylene imine) dendrimers, with a pH-dependent aggregation. Macromolecules, 28(19), 6689-6691. https://doi.org/10.1021/ma00123a043

DOI:

$10.1021 / \mathrm{ma} 00123 \mathrm{a} 043$

Document status and date:

Published: 01/01/1995

\section{Document Version:}

Publisher's PDF, also known as Version of Record (includes final page, issue and volume numbers)

\section{Please check the document version of this publication:}

- A submitted manuscript is the version of the article upon submission and before peer-review. There can be important differences between the submitted version and the official published version of record. People interested in the research are advised to contact the author for the final version of the publication, or visit the $\mathrm{DOI}$ to the publisher's website.

- The final author version and the galley proof are versions of the publication after peer review.

- The final published version features the final layout of the paper including the volume, issue and page numbers.

Link to publication

\footnotetext{
General rights

- You may freely distribute the URL identifying the publication in the public portal. follow below link for the End User Agreement:

www.tue.nl/taverne

Take down policy

If you believe that this document breaches copyright please contact us at:

openaccess@tue.nl

providing details and we will investigate your claim.
}

Copyright and moral rights for the publications made accessible in the public portal are retained by the authors and/or other copyright owners and it is a condition of accessing publications that users recognise and abide by the legal requirements associated with these rights.

- Users may download and print one copy of any publication from the public portal for the purpose of private study or research.

- You may not further distribute the material or use it for any profit-making activity or commercial gain

If the publication is distributed under the terms of Article $25 \mathrm{fa}$ of the Dutch Copyright Act, indicated by the "Taverne" license above, please 


\section{Acid-Functionalized Amphiphiles Derived from Polystyrene-Poly(propylene imine) Dendrimers, with a pH-Dependent Aggregation}

\author{
J. C. M. van Hest, M. W. P. L. Baars, \\ C. Elissen-Román, M. H. P. van Genderen, and \\ E. W. Meijer*
}

Laboratory of Organic Chemistry, Eindhoven University of Technology, P. O. Box 513 , 5600 MB Eindhoven, The Netherlands

Received April 4, 1995

Revised Manuscript Received July 12, 1995

The research interest in the area of dendrimers has shifted from the design of new synthetic routes of these well-defined, highly branched macromolecules to their use as building blocks for new functional materials. ${ }^{1}$ Recent examples are hybrid block copolymers, ${ }^{2}$ new catalytic systems, ${ }^{3}$ liquid crystalline dendrimers, ${ }^{4}$ unimolecular micelles, ${ }^{5}$ hydraamphiphiles, ${ }^{6}$ and the dendritic box. ${ }^{7}$ We have used the unique hydrophilic character of the poly(propylene imine) dendrimers in the preparation of a new class of amphiphilic block copolymers. ${ }^{8}$ These structures, prepared by a divergent dendrimer synthesis onto a primary amine functionalized polystyrene core molecule of $M_{\mathrm{n}}=3.2 \times 10^{3}$, possess the size of traditional block copolymers but the shape of low molecular weight amphiphiles. A remarkable generation-dependent aggregation behavior was observed for these new amphiphiles, that qualitatively followed Israelachvili's theory of the relationship between molecular shape and amphiphile aggregation.

The versatility of these amphiphiles, however, is based not only on the ability of variation of head-group size by using different generations of the dendrimer part but also on the possibility of dendrimer modification. Extensive studies on the traditional poly(propylene imines) have provided us with a number of quantitative modification reactions. ${ }^{9}$ We report our recent results on acid-functionalized surfactants (PS-dendr-(COOH $)_{n}$ ) (Figure 1) that contribute to the interesting area of the amphiphilic dendrimers. ${ }^{2,5,6,8,10}$ Newkome et al. ${ }^{11}$ have already shown the effect of $\mathrm{pH}$ on the radii of end-group acid-functionalized unimolecular micelles. Our structures have both carboxylic acid end groups and tertiary amines in the dendritic head group. This can give rise to a pH-dependent behavior, of which the change in amphiphilicity has our special interest.

The PS-dendr-(COOH $)_{n}(n=2,4,8,16,32)$ series were synthesized by acid hydrolysis of the corresponding nitrile-functionalized structures (Scheme 1 and Table 1) based on a modification of the procedure developed for the traditional poly(propylene imines). ${ }^{9}$

However, due to the amphiphilic character of our structures, the reaction had to be performed in a toluene-concentrated hydrochloric acid ( $1: 1$ by volume) mixture to allow reaction to take place at the interface. PS-dendr-COOH could not be prepared from the corresponding nitrile, probably due to the lack of amphiphilic character.

The amphiphiles were obtained after workup in their protonated form as $\mathrm{HCl}$ salt. Characterization of the amphiphilic structures proved to be possible with IR, ${ }^{1} \mathrm{H}-\mathrm{NMR}$, and ${ }^{13} \mathrm{C}-\mathrm{NMR}$ (DMSO- $d_{6}$ ) spectroscopy. ${ }^{12}$ The latter technique also demonstrated the development of amphiphilic behavior as a function of dendrimer generation (Table 1). In $\mathrm{CDCl}_{3}$ only the polystyrene part of PS-dendr-(COOH $)_{n}$ with $n=4-16$ was discernible, thereby indicating inverted micellar behavior. The higher generations PS-dendr- $(\mathrm{COOH})_{n}$ with $n=8-32$ could easily be dissolved in $\mathrm{D}_{2} \mathrm{O}$ at high $\mathrm{pH}$. In this solvent only the dendrimer block was visible using ${ }^{13} \mathrm{C}$ NMR spectroscopy. The polystyrene block was confined inside the aggregates in this solvent and therefore long relaxation times resulted in broad peaks, which made it impossible to identify this part of the amphiphile. This NMR behavior has, for example, also been reported by Gitsov et al. for their hybrid dendrimer-PEG block copolymers. ${ }^{13}$

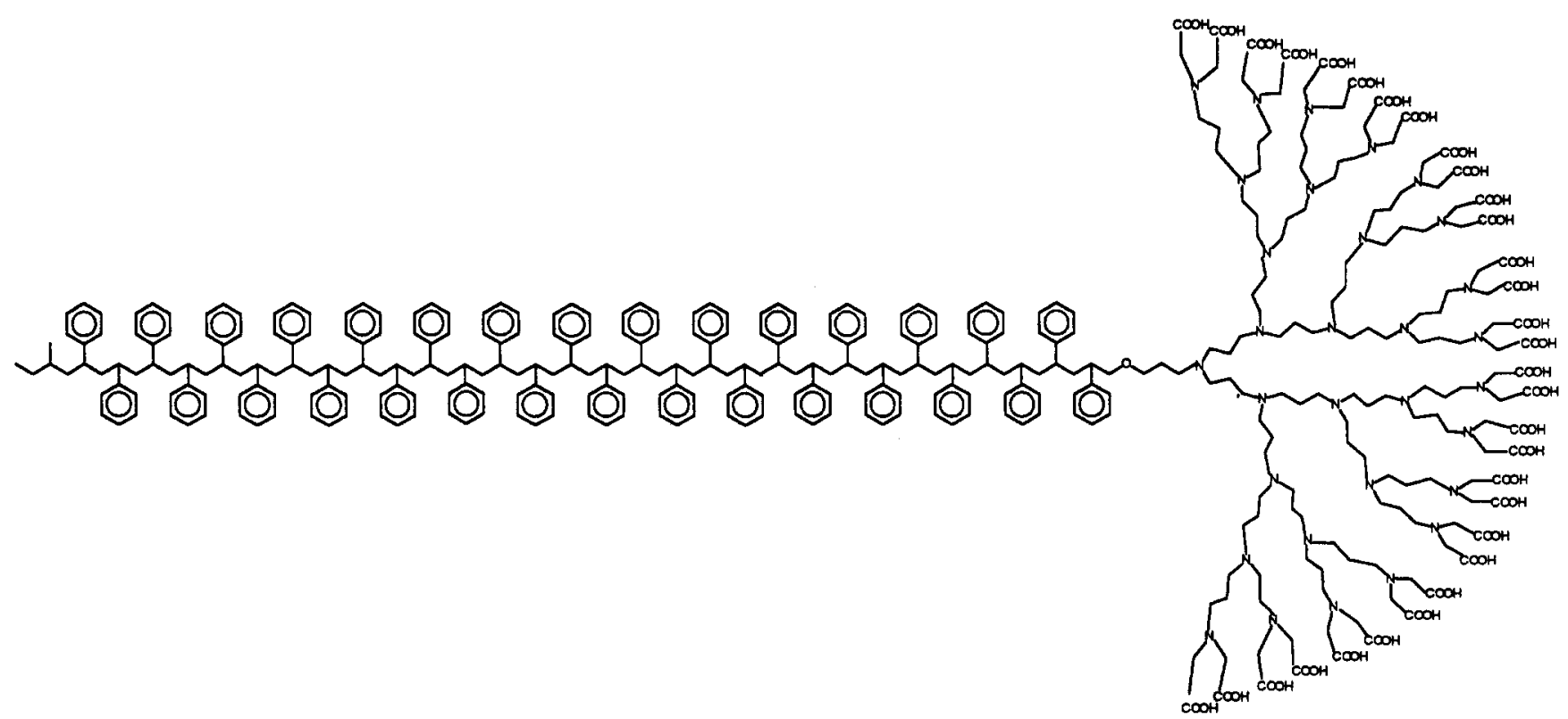

Figure 1. PS-dendr-(COOH $)_{32}$. The nomenclature of the poly(propylene imine) dendrimers is as follows: "PS" stands for polystyrene as the core molecule, in this case a PS chain is used with $M_{\mathrm{n}}=3.2 \times 10^{3}$ and $M_{\mathrm{w}} / M_{\mathrm{n}}=1.05$; “(COOH $)_{32}$ " describes the number and type of dendrimer end groups. PS-dendr-(COOH $)_{32}$ contains a dendrimer of the fifth generation. The term generation refers to the reaction sequence in the dendrimer synthesis. After every sequence the number of end groups is doubled and a new generation is obtained. 
Scheme 1. Modification of Nitrile-Functionalized Dendrimers toward Acid Functionalized Structures

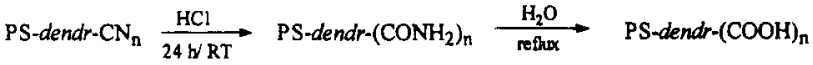

Table 1. PS-dendr-(COOH $)_{n}^{a}$

\begin{tabular}{ccccc}
\hline \multicolumn{1}{c}{ product } & yield (\%) & $\mathrm{CDCl}_{3}$ & DMSO-d $_{6}$ & $\mathrm{D}_{2} \mathrm{O} / \mathrm{NaOD}$ \\
\hline PS-dendr-(COOH$)_{2}$ & 95 & + & + & - \\
PS-dendr-(COOH $)_{4}$ & 93 & $\mathrm{p}$ & + & - \\
PS-dendr-(COOH $)_{8}$ & 85 & $\mathrm{p}$ & + & $\mathrm{d}$ \\
PS-dendr-(COOH) $)_{16}$ & 98 & $\mathrm{p}$ & + & $\mathrm{d}$ \\
PS-dendr-(COOH $)_{32}$ & 94 & - & + & $\mathrm{d}$
\end{tabular}

${ }^{a}$ Yields after workup of PS-dendr-(COOH $)_{n}$ and characterization with ${ }^{13} \mathrm{C}-\mathrm{NMR}$ in different deuterated solvents; + , full characterization, $p$, only polystyrene-block visible; $d$, only dendrimer-block visible, - , no characterization possible.

To investigate the influence of head-group modification on the amphiphilic character of the block copolymers, conductivity measurements were used to study their behavior at the interface of a toluene/water system. ${ }^{14}$ The results are depicted in Figure 2.

The point of phase inversion from water to toluene as a continuous phase is indicated by a conductivity drop to zero. The change of position of this inversion point as a function of $\mathrm{pH}$ and dendrimer generation is a measure for the development of polar and amphiphilic properties of the block copolymers. The behavior of PSdendr $-(\mathrm{COOH})_{n}$ in a $0.01 \mathrm{M} \mathrm{KCl}$ solution is comparable to results of earlier measurements of PS-dendr-(NH$)_{n} .^{8}$ The apolar PS chain is the dominant block for the lowgeneration PS-dendr-(COOH $)_{n}$ with $n=2-8$. Therefore, there is a strong preference for these structures to stabilize toluene as a continuous phase. For PS-dendr$(\mathrm{COOH})_{16}$ a balance is obtained between the apolar and polar part of the amphiphile, resulting in a strongly increased phase inversion point. This structure is equally capable of stabilizing toluene as water as a dispersing phase. At low and high pH, PS-dendr$(\mathrm{COOH})_{n}$ with $n=2-8$ show, compared to the $\mathrm{KCl}$ system, a much better ability to stabilize water as a continuous phase. At low $\mathrm{pH}$ the tertiary amines of PSdendr- $(\mathrm{COOH})_{n}$ are protonated and a polycationic structure is obtained, at high $\mathrm{pH}$ the tertiary amines and carboxylic acid end groups are not protonated, resulting in a negative charge on the dendrimer surface. Both processes result in a net charge and hence follow Newkome's observations for spherical, acid functionalized dendrimers of a sharp increase of dendrimeric diameter due to repulsive interactions. ${ }^{11}$ Therefore, the measured behavior is in line with the increased polarity of these structures. Because of the already good waterstabilizing properties of PS-dendr-(COOH $)_{16}$, its behavior is less influenced by a change of $\mathrm{pH}$. The remarkable upswing in conductivity of PS-dendr-(COOH $)_{16}$ in the $\mathrm{KCl}$ solution is accompanied by a strong viscosity increase of the system. The conductivity increase can therefore be explained by the formation of a laminar phase, that allows conductivity paths to sustain.

Finally, transmission electron microscopy (TEM) was used to study aggregates of PS-dendr-(COOH $)_{n}$ with $n$ $=8-32$, made of samples from aqueous solutions $(\mathrm{pH}$ $\left.=14 ; 3 \times 10^{-4} \mathrm{M}\right)$. Large network structures were observed due to the clustering of the aggregates. Only in the case of PS-dendr- $(\mathrm{COOH})_{8}$ could the single aggregation structures be identified as curved, "wormlike" micelles (Figure 3). This aggregation form is thought to be in between the structures observed for PS-dendr- $\left(\mathrm{NH}_{2}\right)_{8}$ and PS-dendr-( $\left.\mathrm{NH}_{2}\right)_{16},{ }^{8}$ that respec-
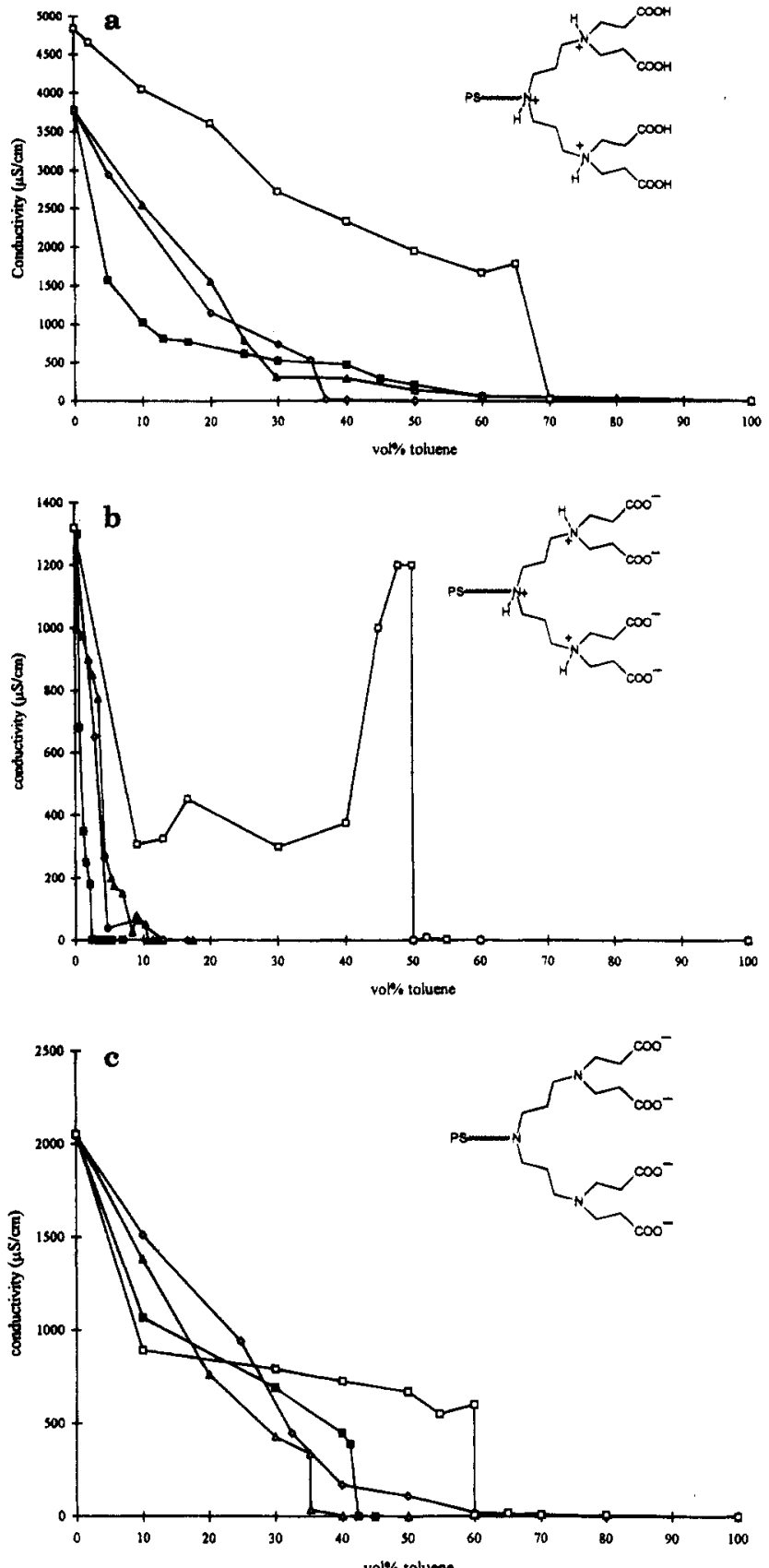

Figure 2. Conductivity measurements of PS-dendr-(COOH $)_{n}$ in toluene/water emulsions at different $\mathrm{pH}$, as a result of different electrolytes used: (a) $0.01 \mathrm{M} \mathrm{HCl}$; (b) $0.01 \mathrm{M} \mathrm{KCl}$; c) $0.01 \mathrm{M} \mathrm{KOH}$. (ם) PS-dendr-(COOH $)_{2} ;(\Delta)$ PS-dend $r$ - $(\mathrm{COOH})_{4}$;

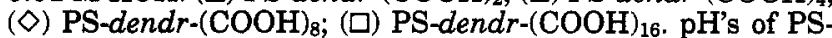
dendr-(COOH $)_{16}$ in aqueous electrolyte solutions were, in the case of $0.01 \mathrm{M} \mathrm{HCl}, \mathrm{pH}=1.9$, for $0.01 \mathrm{M} \mathrm{KCl}, \mathrm{pH}=3.5$, and for $0.01 \mathrm{M} \mathrm{KOH}, \mathrm{pH}=9.1$. The low $\mathrm{pH}$ value at $0.01 \mathrm{M} \mathrm{KCl}$ is a result of the fact that PS-dendr-(COOH $)_{16}$ is added as the $\mathrm{HCl}$ salt in fully protonated form. Because of deprotonation of the carboxylic functions and a $\mathrm{H}^{+} / \mathrm{K}^{+}$exchange, the $\mathrm{pH}$ of the solution is lowered.

tively form flexible bilayers and micellar rods. Preliminary results on critical aggregation concentrations $(\mathrm{CAC})$ of PS-dendr-(COOH$)_{8}, \mathrm{PS}-d e n d r-(\mathrm{COOH})_{16}$, and PS-dendr- $(\mathrm{COOH})_{32}$ gave values of $10^{-6}-10^{-7} \mathrm{M}$ and were determined with pyrene fluorescence probe techniques. ${ }^{15}$ Maybe the concentrations used for the TEM measurements enforce the observed clustering, however, the problem of extreme clustering of aggregates did not occur for the PS-dendr- $\left(\mathrm{NH}_{2}\right)_{n}$ series. A stronger electrostatic interaction between the acid-functionalized 


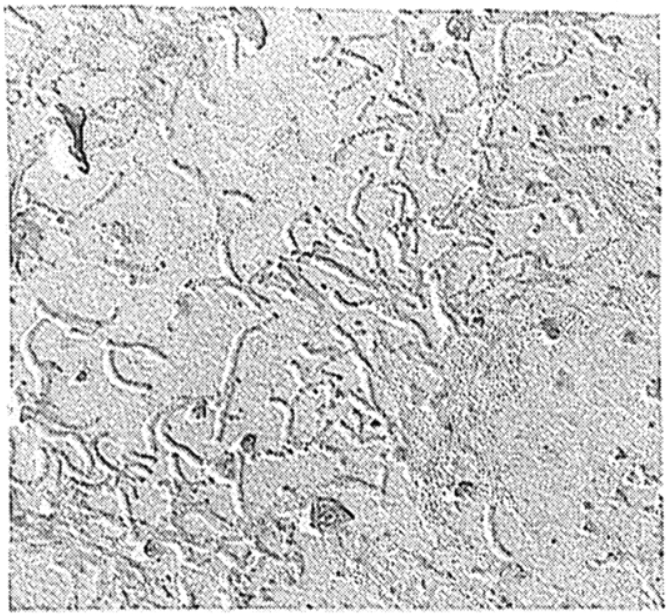

\section{$500 \mathrm{~nm}$}

Figure 3. TEM picture of PS-dendr- $(\mathrm{COOH})_{8}$, prepared by a Pt-shadowing technique. The used enlargement was $23000 \times$.

dendrimer head groups, therefore, also has to be taken into account.

In conclusion, we have shown that head-group modification of amphiphilic polystyrene-poly(propylene imine) dendrimers is possible and that $\mathrm{pH}$-dependent amphiphilic behavior can be observed. The versatility of the dendrimer provides us with a new class of amphiphilic block copolymers of which the properties can be varied by changing both head-group size and polarity.

Acknowledgment. We thank E. M. M. de Brabander-van den Berg (DSM Research) for discussions on dendrimer synthesis and $\mathrm{H}$. van Nunen and $\mathrm{H}$. Geurts (Nijmegen University) for assistance with the TEM measurements. DSM Research is acknowledged for an unrestricted research grant.

\section{References and Notes}

(1) Issberner, I.; Moors, R.; Vögtle, F. Angew. Chem. 1994, 106, 2507. Newkome, G. R.; Yao, Z.-q.; Baker, G. R.; Gupta, V. K. J. Org. Chem. 1985, 50, 2003. Tomalia, D. A.; Naylor, A. M.; Goddard III, W. A. Angew. Chem. 1990, 102, 119. Hawker, C. J.; Fréchet, J. M. J. J. Am. Chem. Soc. 1990,
112, 7638. de Brabander-van den Berg, E. M. M.; Meijer, E. W. Angew. Chem. 1993, 105, 1370.

(2) Gitsov, I.; Wooley, K. L.; Hawker, C. J.; Ivanova, P.; Fréchet, J. M. J. Macromolecules 1993, 26, 5621. Gitsov, I.; Fréchet, J. M. J. Macromolecules 1993, 26, 6536. Gitsov, I.; Fréchet, J. M. J. Macromolecules 1994, 27, 7309.

(3) Knapen, J. W. J.; van der Made, A. W.; de Wilde, J. C.; van Leeuwen, P. W. N. M.; Grove, D. M.; van Koten, G. Nature 1994, 372, 659 .

(4) Percec, V.; Chu, P.; Kawasumi, M. Macromolecules 1994, $27,4441$.

(5) Newkome, G. R.; Nayak, A.; Behera, R. K.; Moorefield, C. N.; Baker, G. R. J. Org. Chem. 1992, 57, 358. Hawker, C. J.; Wooley, K. L.; Fréchet, J. M. J. J. Chem. Soc., Perkin. Trans. 1 1993, 1287. Newkome, G. R.; Moorefield, C. N.; Keith, J.; Baker, G. R.; Escamillo, G. Angew. Chem. 1994, 106, 701 .

(6) Chapman, T. M.; Hillyer, G. L.; Mahan, E. J.; Shaffer, K. A. J. Am. Chem. Soc. 1994, 116, 11195.

(7) Jansen, J. F. G. A.; de Brabander-van den Berg, E. M. M.; Meijer, E. W. Science 1994, 266, 1226.

(8) van Hest, J. C. M.; Baars, M. W. P. L.; Delnoye, D. A. P. van Genderen, M. H. P.; Meijer, E. W. Science 1995, 268, 1592.

(9) Jansen, J. F. G. A.; de Brabander-van den Berg, E. M. M.; Meijer, E. W., in preparation.

(10) Zhong, X. F.; Eisenberg, A. Macromolecules 1994, 27, 1751, 4914.

(11) Newkome, G. R.; Young, J. K.; Baker, G. R.; Potter, R. L.; Audoly, L.; Cooper, D.; Weis, C. D. Macromolecules 1993, $26,2394$.

(12) Characterization of PS-dendr-(COOH $)_{32}:{ }^{13} \mathrm{C}-\mathrm{NMR}$ (DMSO$\left.d_{6}\right) \delta 17.8\left(30 \mathrm{C}, \mathrm{NCH}_{2} \mathrm{CH}_{2} \mathrm{CH}_{2} \mathrm{~N}\right), 28.6\left(32 \mathrm{C}, \mathrm{NCH}_{2} \mathrm{CH}_{2-}\right.$ $\mathrm{COOH}), 39-45.0$ ( $\left.\mathrm{CH}_{2} \mathrm{CHPh}\right), 48.1$ (32 C, $\mathrm{NCH}_{2} \mathrm{CH}_{2} \mathrm{COOH}$ ), $49.3\left(61 \mathrm{C}, \mathrm{NCH}_{2} \mathrm{CH}_{2} \mathrm{CH}_{2} \mathrm{~N}\right), 125.7\left(\mathrm{CH}_{2} \mathrm{CH} P h_{\text {para }}\right), 127.2-$ $128.8\left(\mathrm{CH}_{2} \mathrm{CH} P h_{\text {ortho+meta }}\right), 145.5\left(\mathrm{CH}_{2} \mathrm{CH} P h_{\text {ipso }}\right), 171.6$ (32 C, $C O O H)$; IR: $v_{\mathrm{C}=0} 1706 \mathrm{~cm}^{-1}$.

(13) Gitsov, I.; Wooley, K. L.; Fréchet, J. M. J. Angew. Chem. $1992,104,1282$.

(14) The experiments were performed batchwise at $20^{\circ} \mathrm{C}$, using a Philips PW9550 conductivity cell. The total amount of solvent $\left(\mathrm{H}_{2} \mathrm{O}\right.$ and toluene) was $23 \mathrm{~mL}$, containing $3 \times 10^{-4}$ $\mathrm{M}$ amphiphile. The same stirring speed was used for all experiments; measurements were performed after 2 min of equilibration time. The $\mathrm{pH}$-dependent amphiphilic behavior of PS-dendr-(COOH $)_{n}(n=2-32)$ was investigated using three different electrolytes: $0.01 \mathrm{M} \mathrm{KCl}, 0.01 \mathrm{M} \mathrm{HCl}$, and $0.01 \mathrm{M} \mathrm{KOH}$. PS-dendr- $(\mathrm{COOH})_{32}$ is left out of the figures, because this structure did not show amphiphilic behavior and a dilution curve was measured instead of a phase inversion. Conductivity measurements of toluene/water mixtures without the addition of amphiphile were not possible, because in these cases no stable emulsions were formed.

(15) Elissen-Román, C.; et al., results to be published. Astafieva, I. Zhong, X. F.; Eisenberg, A. Macromolecules 1993, 26, 7339. Wilhelm, M.; Zhao, C. L.; Wang, Y.; Xu, R.; Winnik, M. A. Macromolecules 1991, 24, 1033.

MA9504532 